Scientific Review - Engineering and Environmental Sciences (2018), 27 (1), 28-41

Sci. Rev. Eng. Env. Sci. (2018), 27 (1)

Przegląd Naukowy - Inżynieria i Kształtowanie Środowiska (2018), 27 (1), 28-41

Prz. Nauk. Inż. Kszt. Środ. (2018), 27 (1)

http://iks.pn.sggw.pl

DOI 10.22630/PNIKS.2018.27.1.4

\title{
Barbara PAWLOWSKA
}

Wydział Ekonomiczny, Uniwersytet Gdański

Faculty of Economics, University of Gdańsk

\section{Koszty zewnętrzne transportu w Polsce External costs of transport in Poland}

Słowa kluczowe: koszty zewnętrzne, transport, internalizacja kosztów zewnętrznych, polityka transportowa

Key words: external costs, transport, internalisation of external costs, transport policy

\section{Wprowadzenie}

Problemy związane z ochroną środowiska przyrodniczego przed szkodliwym wpływem prowadzonej przez człowieka działalności gospodarczej to jedno z istotniejszych wyzwań współczesności. Zagadnienia te dotyczą wykorzystania zasobów naturalnych, zanieczyszczenia środowiska, zmian klimatycznych, niszczenia naturalnych siedlisk wielu gatunków roślin i zwierząt, wymierania gatunków czy wreszcie zagrożenia całych ekosystemów. Z uwagi na związany ze wzrostem populacji ludzkiej wzrost konsumpcji zmiany te wpływają na zwiększenie zagrożenia dla bezpieczeństwa ludzi oraz zdrowia i dobrobytu społeczeństw. Należy zdawać sobie sprawę, że powiązania środowiskowe na lokalnym, regionalnym, krajowym czy globalnym poziomie mają charakter systemowy, pozostają we wzajemnych sprzężeniach, które jeszcze w pełni nie zostały zidentyfikowane.

Transport już w latach 90. ubiegłego wieku został uznany za jeden z najuciążliwszych sektorów ludzkiej działalności. Niestety ta tendencja nadal się utrzymuje. W aspekcie transportu do zagrożeń związanych z naruszeniem równowagi w ekosystemie dochodzą jeszcze problemy wypadków transportowych i związane $\mathrm{z}$ nimi straty materialne i ludzkie (Pawłowska, 2017).

Odpowiedziązestrony politykinawymienione problemy jest obecna w większości dokumentów programowych Unii Europejskiej koncepcja zrównoważonego rozwoju zarówno w skali całej gospodarki ugrupowania, jak i w programach sektorowych. Koncepcja zrównoważonego rozwoju transportu jest reakcją na niepowodzenia polityki transportowej drugiej połowy XX wieku Nie- 
zrównoważony transport powoduje zanieczyszczenie środowiska naturalnego, pochłania ogromne ilości energii, a wzrost nakładów inwestowanych w tę sferę nie poprawia w oczekiwanym stopniu poziomu jakości świadczonych usług. Celem artykułu jest przegląd dostępnych badań nad metodami szacowania kosztów zewnętrznych i prezentacja wyników własnych estymacji tych kategorii kosztowych dla transportu w Polsce z wykorzystaniem metod stosowanych i zalecanych przez Komisję Europejską. $\mathrm{Z}$ uwagi na postawiony cel w pracy wykorzystano przede wszystkim metodę przeglądu literatury, która pozwoliła na przeprowadzenie analizy porównawczej metod szacowania kosztów poszczególnych kategorii efektów zewnętrznych transportu oraz uwzględnienie rozwoju tych metod od momentu opublikowania podręcznika rekomendowanego przez Komisję Europejską (Maibach i in., 2008). Do analizy efektów zewnętrznych wykorzystano metodę systemowa, która narzuca konieczność uwzględnienia wszystkich aspektów badanego problemu. Na podstawie studiów literatury i przeprowadzonej analizy statystycznej efektów zewnętrznych transportu dokonano estymacji kosztów dla polskiego transportu. Wiedza na temat poziomu kosztów zewnętrznych transportu jest podstawą działań w zakresie internalizacji tych kosztów i doboru właściwych instrumentów polityki transportowej.

\section{Efekty i koszty zewnętrzne transportu}

Rozwój sektora transportowego jest bardzo ściśle powiązany $\mathrm{z}$ procesem rozwoju społeczno-gospodarczego na zasadzie sprzężeń zwrotnych. Transport zbliża do siebie rynki, umożliwia zwiększenie produkcji, aktywizuje regiony wokół infrastruktury, czyli jest sektorem gospodarki narodowej umożliwiającym pozostałym jej działom sprawne i efektywne funkcjonowanie (Koźlak, 2012). Transport jest też źródłem wielu znaczących, negatywnych dla społeczeństwa i gospodarki efektów zewnętrznych, co pociaga za soba znaczne koszty społeczne. W związku z tym, że większość $\mathrm{z}$ nich to koszty zewnętrzne, nie maja one odzwierciedlenia $w$ cenach rynkowych płaconych przez użytkowników transportu (Pawłowska, 2013). Efekty zewnętrzne transportu odnoszą się do sytuacji, w której użytkownik transportu albo nie płaci wszystkich kosztów związanych $\mathrm{z}$ procesem transportowym (w tym kosztów środowiskowych, kongestii czy wypadków drogowych), albo nie otrzymuje pełnych korzyści z nimi związanych (EC, 1995). Do takiej sytuacji najczęściej dochodzi, gdy podmioty użytkują wspólnie zasoby, dla których brak jasno sprecyzowanych praw własności (Baumol i Oates, 1988).

Lista efektów zewnętrznych transportu jest stosunkowo długa (Pawłowska, 2000). Wynika to z tego, że transport jest jednym z najważniejszych sektorów współczesnej uprzemysłowionej gospodarki i nowoczesnego społeczeństwa. Transport przede wszystkim użytkuje ogromne tereny na rozwój infrastruktury transportowej zarówno punktowej, jak i liniowej oraz poważnie zanieczyszcza powietrze atmosferyczne, wody i gleby. Ponadto działalność transportowa zniekształca naturalną rzeźbę terenu oraz krajobraz, powodując defragmentacje ekosystemu, narusza strukturę podłoża 
skalnego, dewastuje świat roślinny i zagraża faunie. Transportu niekorzystnie wpływa na organizm ludzki, powodując zagrożenie jego zdrowia i życia.

Uogólniając, możemy wyróżnić cztery obszary w transporcie, w których pojawiają się efekty zewnętrzne (Rothengater, 2000). Po pierwsze rozbudowa infrastruktury może prowadzić zarówno do pozytywnych, jak i negatywnych efektów zewnętrznych, które nie są uwzględniane w transakcjach rynkowych. Po drugie użytkownicy wewnątrz sektora transportu mogą oddziaływać na siebie wzajemnie, co prowadzi do niezamierzonych interakcji powodujących nieefektywność sektora. Po trzecie schemat finansowy płatności za użytkowanie infrastruktury może okazać się zafałszowany ze względu na niesprawiedliwy podział przepływów finansowych, tj. podatnicy płacą znacznie więcej niż wynosi wartość usług publicznych wynikających z funkcjonowania infrastruktury, a użytkownicy prywatni płacą poniżej rzeczywistych kosztów użytkowania infrastruktury. Czwarty obszar wynika z tego, że działalność odbywająca się na/ /lub dzięki infrastrukturze transportowej oddziałuje na osoby trzecie spoza sektora transportu w sposób, który powoduje wysyłanie fałszywych sygnałów i prowadzi do nieefektywności rynku.

W wymiarze finansowym społeczne koszty transportu obejmują wszystkie te, które wiążą się z budową i utrzymaniem infrastruktury transportowej, jak również prowadzeniem działalności transportowej. Do kosztów tych należą prywatne (wewnętrzne) koszty, które ponoszone są przez użytkowników transportu w momencie podjęcia przez nich decyzji, kiedy i jak użytkują infrastrukturę transportu, i są nakładane na użytkownika przez rynek. Drugą grupę kosztów społecznych stanowią te, które nie są przenoszone na użytkownika przez rynek. Nie ma na rynku cen odnoszących się do tych kosztów, które wpływałyby na decyzje podmiotów. Tę grupę kosztów określa się mianem kosztów zewnętrznych. Do tych kosztów można zaliczyć między innymi takie grupy kosztów, jak: wyczerpywanie nieodnawialnych zasobów naturalnych; degradacja środowiska przyrodniczego; zagrożenie zdrowia i życia ludzi; niepokryte koszty infrastruktury i inne nieskompensowane zużycie materialnych zasobów; koszty interakcji podmiotów w otoczeniu systemu transportowego, np. kongestia. Tabela 1 pokazuje podział społecznego kosztu transportu na prywatne i zewnętrzne według poszczególnych pozycji.

Obok wyżej wymienionych kategorii istotne są również tzw. koszty pośrednie działalności transportowej (ang. up-and downstream processes cost), które do tej pory rzadko były szacowane, co powodowało zaniżenie kosztów. Do tej grupy kosztów zalicza się koszty zanieczyszczenia powietrza i zmian klimatycznych powstałe przy produkcji energii elektrycznej i paliw dla transportu, koszty emisji związanych z produkcją i utrzymaniem środków oraz infrastruktury transportu, a także koszty zagospodarowania odpadów pochodzących z działalności transportowej. Ta grupa kosztów często jest pomijana w szacunkach kosztów społecznych transportu $z$ uwagi na trudności w ich estymacji. 
TABELA 1. Struktura społecznych kosztów transportu (Bąk i Pawłowska, 2008)

TABLE 1. Structure of social costs in transport (Bąk and Pawłowska, 2008)

\begin{tabular}{|c|c|c|}
\hline \multirow{2}{*}{$\begin{array}{l}\text { Kategorie kosztów } \\
\text { Cost components }\end{array}$} & \multicolumn{2}{|c|}{$\begin{array}{l}\text { Koszt społeczny } \\
\text { Social cost }\end{array}$} \\
\hline & $\begin{array}{l}\text { wewnętrzny koszt } \\
\text { internal cost }\end{array}$ & $\begin{array}{l}\text { zewnętrzny koszt } \\
\text { external cost }\end{array}$ \\
\hline $\begin{array}{l}\text { Wydatki transportowe } \\
\text { Transport expenditures }\end{array}$ & $\begin{array}{l}\text { koszty paliwa, środków transportu, } \\
\text { biletów/przewoźnego }\end{array}$ & $\begin{array}{l}\text { koszty płacone przez inne podmio- } \\
\text { ty (np. wydatki na budowę miejsc } \\
\text { parkingowych) }\end{array}$ \\
\hline $\begin{array}{l}\text { Koszty infrastruktury } \\
\text { Infrastructure costs }\end{array}$ & $\begin{array}{l}\text { opłaty użytkowników, podatki od } \\
\text { środka transportu, podatki paliwowe }\end{array}$ & nie pokryte koszty infrastruktury \\
\hline $\begin{array}{l}\text { Koszty wypadków } \\
\text { Accident costs }\end{array}$ & $\begin{array}{l}\text { koszty pokrywane z ubezpieczenia, } \\
\text { własne koszty wypadku }\end{array}$ & $\begin{array}{l}\text { nie pokryte koszty wypadków } \\
\text { (ból, cierpienie spowodowane } \\
\text { u innych podmiotów) }\end{array}$ \\
\hline $\begin{array}{l}\text { Koszty środowiskowe } \\
\text { Environmental costs }\end{array}$ & $\begin{array}{l}\text { straty ponoszone przez użytkowni- } \\
\text { ków }\end{array}$ & $\begin{array}{l}\text { nie pokryte koszty środowiska } \\
\text { naturalnego }\end{array}$ \\
\hline $\begin{array}{l}\text { Koszty kongestii } \\
\text { Congestion costs }\end{array}$ & $\begin{array}{l}\text { koszt straty czasu ponoszone } \\
\text { przez użytkowników }\end{array}$ & $\begin{array}{l}\text { opóźnienia, straty czasu innych } \\
\text { członków społeczeństwa }\end{array}$ \\
\hline
\end{tabular}

\section{Założenia metodologiczne dotyczące procedur i metod szacunku kosztów zewnętrznych transportu w badaniach Unii Europejskiej}

Estymacja i internalizacja kosztów zewnętrznych transportu od początku lat 90. ubiegłego wieku są istotnymi przedmiotami badawczymi. Nowe spojrzenie na te zagadnienie zostało wymuszone przez bardzo duże efekty zewnętrzne generowane przez sektor transportu i ich skutki odczuwane przez użytkowników transportu. W okresie ostatnich ponad 25 lat wiele badań w ramach licznych projektów badawczych zarówno w skali UE, jak i poszczególnych krajów członkowskich było prowadzonych w celu rozwijania metod szacowania kosztów zewnętrznych transportu. Jako najbardziej istotne z uwagi na efekty i możliwość zastosowania tych wyników w skali UE ocenia się takie projekty, jak (PE, 2009): UNITE (1998-2002), GRACE (2005-2008), HEATCO (2004-2006), CAFE CBA (2005-2006), TREMOVE (ostatnia aktualizacja modelu 2009-2010) czy IMPACT (2006-2008) ${ }^{1}$.

Szacunki kosztów zewnętrznych transportu są obciążone dużym marginesem błędu. Istnieje jednak zgoda wśród badaczy tego zagadnienia co do głównych kwestii metodologicznych. Okazuje się, że pomimo wieloletnich doświadczeń krajów wysokorozwiniętych

${ }^{1}$ Projekt IMPACT (ang. Internalisation Measures and Policies for All External Cost of Transport) był realizowany przez konsorcjum kierowane przez holenderski instytut CE Delft. W jego skład wchodził również zespół Uniwersytetu Gdańskiego. Obecnie publicznie dostępny na stronie internetowej Komisji Europejskiej jest jeden z efektów projektu - podręcznik na temat szacunku kosztów zewnętrznych (Maibach i in., 2008). 
w badaniach skutków i kosztów zewnętrznych transportu nadal istnieją nie tylko rozbieżności w ujęciach i metodach badawczych, ale nawet $\mathrm{w}$ terminologii oraz zasadach definiowania pojęć i zjawisk (Maibach i in., 2008).

Większość badań podejmowanych do tej pory nad efektami zewnętrznymi działalności transportowej przeprowadzono z wykorzystaniem metody analizy zstępującej (ang. top-down approach), polegającej na tym, że przy kalkulacji kosztów jednostkowych „wychodzi się” od kosztów całkowitych dla danego obszaru (np. kraju, regionu, miasta), następnie alokuje się te koszty na poszczególne sektory/branże zgodnie $\mathrm{z}$ ich udziałem w zanieczyszczeniu bacdź wielkością produkcji/aktywności (Maibach i in., 2008). Poczynione założenie oznacza, że udział w zanieczyszczeniu odpowiada udziałowi w stratach spowodowanych przez to zanieczyszczenie, co prowadzi do pewnych uproszczeń. Nie uwzględnia się wzajemnych interakcji na styku przyczyna - skutek oraz intensywności oddziaływania po przekroczeniu pewnych wartości referencyjnych. Tak więc efektem tych szacunków są przeciętne koszty, a nie krańcowe.

Inne podejście stosuje metodę analizy wstępującej (ang. bottom-up approach), czyli korzysta się z konkretnych studiów przypadków w określonych warunkach zewnętrznych. Zaletą tego podejścia jest zastosowanie $\mathrm{u}$ podstaw precyzyjnych i dokładnych kalkulacji. Wykorzystanie tej metody jest jednak stosunkowo kosztowne, a ponadto trudno jest na podstawie szczególnych przypadków przeprowadzić agregację i uogólnienie wyników. W tabeli 2 zaprezentowano najczęściej wykorzystywane metody estymacji poszczególnych kategorii kosztów zewnętrznych transportu.

Istniejąca literatura ekonomiczna i wyniki badań prowadzonych w dwóch ostatnich dekadach dowodzą, że efektywna polityka ustalania kosztów społecznych w transporcie powinna bazować na podejściu stosującym metodę analizy wstępującej, a konkretnie metodę IPA. Jednak w praktyce najczęściej znajduje zastosowanie połączenie metod analizy wstępującej i zstępującej.

\section{Koszty zewnętrzne transportu w Unii Europejskiej}

W tej części artykułu przedstawione zostaną wyniki ostatnich kalkulacji kosztów zewnętrznych transportu dla 27 krajów europejskich. W badaniu z 2011 roku w skład badanych krajów weszło 5 krajów członkowskich UE (bez Malty i Cypru) oraz Szwajcaria i Norwegia (van Essen i in., 2011). Zaprezentowane w dalszej części artykułu szacunki są kontynuacją badań nad kosztami zewnętrznymi rozpoczętych w 1995 roku przezdwa instytuty: szwajcarski INFRAS i niemiecki IWW. Badaniem objęto cztery gałęzie transportu: transport drogowy, kolejowy, lotniczy i żeglugę śródlądową. Nie uwzględniono natomiast transportu morskiego. W transporcie kolejowym koszty sklasyfikowano oddzielenie dla przewozów pasażerskich i towarowych oraz uwzględniono rodzaj trakcji: spalinową i elektryczną. W transporcie drogowym również dokonano podziału na przewozy osób i ładunków, przy czym oddzielnie skategoryzowano samochody osobowe, autobusy i autokary oraz motocykle. W przewozach ładunków wydzie- 
TABELA 2. Dobre praktyki w metodologii szacowania komponentów kosztów zewnętrznych transportu (Link i in., 2007; Maibach i in., 2008)

TABLE 2. Best practice valuation approaches for external cost components in transport (Link et al., 2007; Maibach et al., 2008)

\begin{tabular}{|c|c|}
\hline $\begin{array}{l}\text { Kategoria kosztu } \\
\text { Cost component }\end{array}$ & $\begin{array}{l}\text { Zalecane podejście } \\
\text { Best practice approach }\end{array}$ \\
\hline $\begin{array}{l}\text { Koszty niedoboru infrastruktury } \\
\text { Cost of scarce in infrastructure }\end{array}$ & $\begin{array}{l}\text { WTP w celu oszacowania wartości czasu (według meto- } \\
\text { dę preferencji ujawnionych SP). Alternatywnie: WTA. } \\
\text { WTP dla oszacowania ograniczeń w dostępie do infra- } \\
\text { struktury (według metody SP). Alternatywnie: WTA. }\end{array}$ \\
\hline $\begin{array}{l}\text { Koszty wypadków } \\
\text { Accident costs }\end{array}$ & $\begin{array}{l}\text { Koszt zasobów dla oszacowania kosztów ofiar rannych. } \\
\text { WTP do wyceny statystycznego życia ludzkiego według } \\
\text { metody SP dla zredukowania współczynnika ryzyka } \\
\text { wypadku. Alternatywnie: WTA. }\end{array}$ \\
\hline $\begin{array}{l}\text { Koszty zanieczyszczenia powietrza } \\
\text { i koszty opieki medycznej } \\
\text { Air pollution and human health costs }\end{array}$ & $\begin{array}{l}\text { Metoda IPA wykorzystująca koszt zasobów i WTP do } \\
\text { wyceny długości życia ludzkiego (skrócenie długości } \\
\text { życia). Alternatywnie: WTA. }\end{array}$ \\
\hline $\begin{array}{l}\text { Koszty zanieczyszczenia powietrza } \\
\text { i niszczenia budynków/konstrukcji } \\
\text { Air pollution and building/material } \\
\text { damages costs }\end{array}$ & Metoda IPA wykorzystująca koszty restytucji. \\
\hline $\begin{array}{l}\text { Koszty zanieczyszczenia powietrza i strat } \\
\text { bioróżnorodności } \\
\text { Air pollution and loses in biodiversity costs }\end{array}$ & $\begin{array}{l}\text { Metoda IPA wykorzystująca koszty strat (np. straty } \\
\text { w uprawach). }\end{array}$ \\
\hline $\begin{array}{l}\text { Koszty hałasu } \\
\text { Noise costs }\end{array}$ & $\begin{array}{l}\text { Metoda kosztów strat: podejście WTP na podstawie cen } \\
\text { hedonicznistycznych (straty w wartości nieruchomości) } \\
\text { lub SP w celu redukcji uciążliwości hałasu. } \\
\text { Koszty opieki zdrowotnej: podejście IPA dla zdrowia } \\
\text { ludzkiego z użyciem WTP. }\end{array}$ \\
\hline $\begin{array}{l}\text { Koszty zmian klimatycznych } \\
\text { Climate change costs }\end{array}$ & $\begin{array}{l}\text { Metoda kosztów strat i metoda unikania, założenie } \\
\text { liniowej zależności między kosztami a emisją gazów } \\
\text { cieplarnianych, tzw. shadow prices w Europejskim } \\
\text { systemie handlu emisjami. }\end{array}$ \\
\hline $\begin{array}{l}\text { Koszty defragmentacji terenu i zmian } \\
\text { w krajobrazie } \\
\text { Nature and landscape costs }\end{array}$ & Model inwentaryzacji ciagłej - PIM. \\
\hline
\end{tabular}

WTP - willingness to pay (gotowość do zapłacenia), WTA - willingness to accept (gotowość do zaakceptowania), SP - stated preference approach (metoda preferencji ujawnionych), IPA - impact pathway approach, PIM - perpetual inventory model (model inwentaryzacyjny ciagłej), shadow price - wartość pieniężna przypisana do abstrakcyjnych lub trudnych do obliczenia kosztów.

lono dwie grupy: samochody dostawcze do 3,5 t oraz samochody ciężarowe. $\mathrm{W}$ transporcie lotniczym ujęto przewozy pasażerskie, a w żegludze śródlądowej jedynie przewozy ładunków.
W estymacji kosztów zewnętrznych transportu uwzględniono 10 kategorii, które podzielono na dwie grupy: koszty podstawowe i pozostałe. Do podstawowej grupy zaliczono koszty: wypadków; 


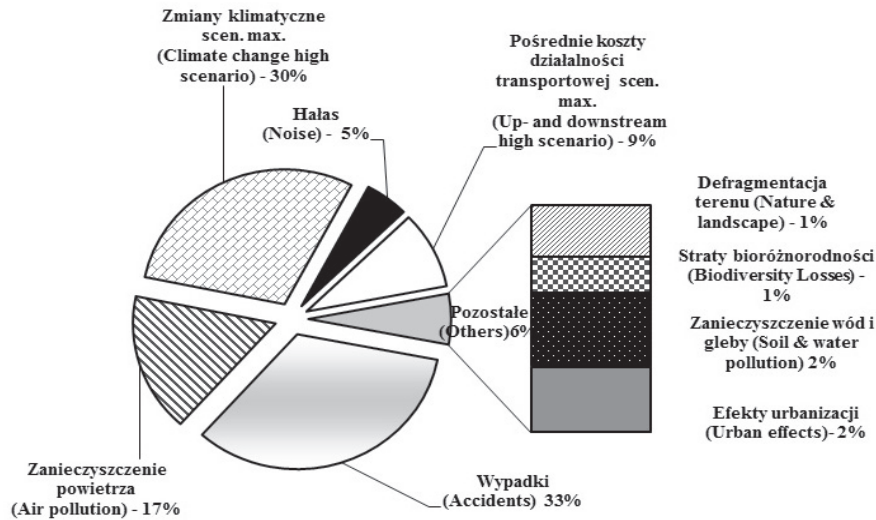

przewozy pasażerskie

passenger transport

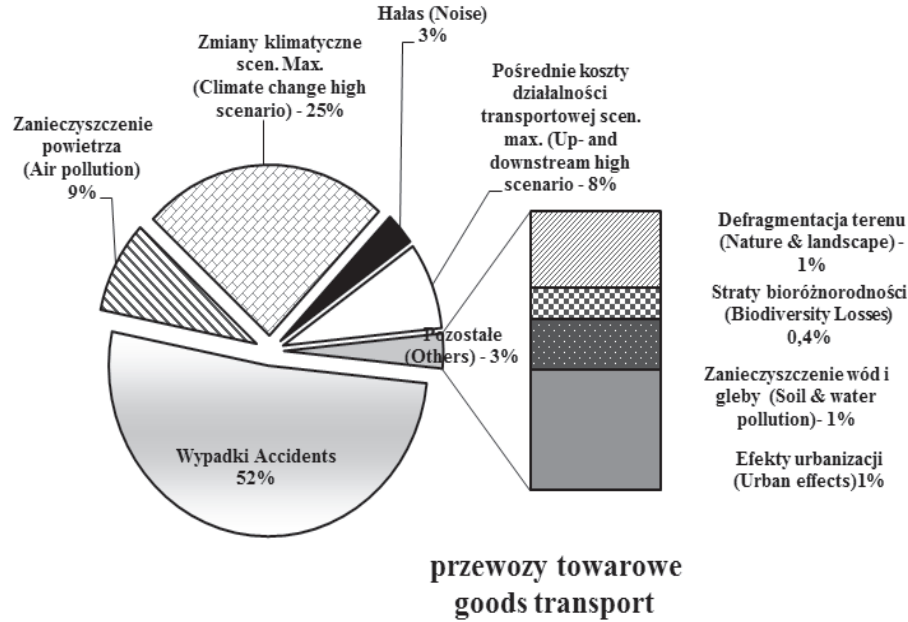

RYSUNEK. Struktura całkowitych kosztów zewnętrznych w przewozach pasażerskich w UE-25 ze Szwajcarią i z Norwegią w 2008 roku według poszczególnych kategorii kosztów (van Essen i in., 2011)

FIGURE. Share of the different cost categories on total external costs 2008 for EU-25 with Norway and Switzerland (van Essen et al., 2011)

hałasu; zanieczyszczenia powietrza; zmian klimatycznych; koszty pośrednie działalności transportowej. Kategoria pozostałe obejmuje koszty: defragmentacji terenu; strat bioróżnorodności; zanieczyszczenia wód; gleby; efektów urbanizacji. W kalkulacjach nie uwzględniono kosztów kongestii (jedynie częściowo w transporcie drogowym). Wszystkie koszty z 2008 roku oszacowano zostały $w$ euro.

Całkowity koszt zewnętrzny transportu dla 25 krajów członkowskich UE-25, Norwegii i Szwajcarii w 2008 ro- 
ku oszacowany został $\mathrm{w}$ ramach prowadzonych badań na 514 mld EUR (tab. 3). Odpowiada to 4\% PKB wypracowanego $\mathrm{w}$ tym regionie. $\mathrm{Na}$ rysunku przedstawiono strukturę kosztów zewnętrznych w przewozach pasażerskich i towarowych według kategorii badanych kosztów.

Najwyższą pozycję kosztową w strukturze kosztów zewnętrznych zarówno w przewozach osób, jak i ładunków stanowią wypadki drogowe - odpowiednio 52 i 33\%. Traktując transport jako całość, udział tej kategorii kosztowej wyniósł w 2008 roku 44\%. Kolejną kategorią kosztową są koszty zmian klimatycznych i stanowią one $29 \%$ dla całego transportu - odpowiednio $25 \%$ dla przewozów osób i 30\% dla ładunków. Koszty zanieczyszczenia powietrza to kolejna kategoria kosztowa stanowiąca $10 \%$ całkowitych kosztów zewnętrznych, przy czym w przewozach ładunków jest to aż 17\%, a w przewozach osób tylko 9\%. Bardzo wysoko w strukturze kosztów zewnętrznych transportu znajdują się koszty pośrednie działalności transportowej - na poziomie 8 i 9\%. Kolejna kategoria kosztowa to hałas z udziałem $4 \%$, a pozostałe koszty stanowią 3\% w przewozach osób i $6 \% \mathrm{w}$ przewozach ładunków.

Analizując strukturę gałęziową kosztów zewnętrznych transportu, należy stwierdzić, że dominujący udział w niej ma transport drogowy. Stanowi on 92,5\% kosztu całkowitego, z czego 76\% przypada na przewozy osób, a 24\% na transport ładunków. Samochody osobowe powodują $61 \%$ kosztów, a autobusy i autokary tylko 4\%. Kolejne $6 \%$ przypada na motocykle. Samochody ciężarowe przyczyniają się do 13\% kosztów, a samochody dostawcze do 9\%. Drugą co do uciążliwości społecznej gałęzią jest transport lotniczy. Jego koszty zewnętrzne stanowią około 5,3\% kosztów całkowitych. Na transport kolejowy przypada udział 1,9\%, a żegluga śródlądowa stanowi tylko $0,3 \%$.

\section{Koszty zewnętrzne transportu w Polsce}

Posługując się metodologią zastosowaną w badaniach dla krajów UE i stosując wartości referencyjne, przeprowadzono estymacje kosztów zewnętrznych transportu dla Polski. W tabeli 4 przedstawiono szacunki kosztów zewnętrznych transportu w Polsce w 2014 roku. Obliczeń dokonano na podstawie wyliczenia jednostkowych przeciętnych kosztów zewnętrznych transportu zaprezentowanych $\mathrm{w}$ raporcie $\mathrm{CE}$ Delft (van Essen i in., 2011) i w uaktualnionym w 2014 roku podręczniku estymacji kosztów zewnętrznych transportu (EC, 2014). Wszelkie wartości skorygowano o parytet siły nabywczej PPP.

Całkowite koszty zewnętrzne transportu w 2014 roku w Polsce wyniosły 21,4 mld EUR przy założeniach scenariusza maksymalistycznego i 15,4 mld EUR przy założeniach minimalistycznego scenariusza. Stanowi to około 5\% PKB w wariancie maksymalnym i 3\% $\mathrm{W}$ wariancie minimalnym. Scenariusze wykorzystano do oszacowania kosztów zmian klimatycznych i kosztów pośrednich transportu.

Analizując szacunki kosztów, można stwierdzić, że największy udział w kosztach zewnętrznych zarówno w przewozach pasażerskich, jak i towarowych miały koszty wypadków - odpowiednio 


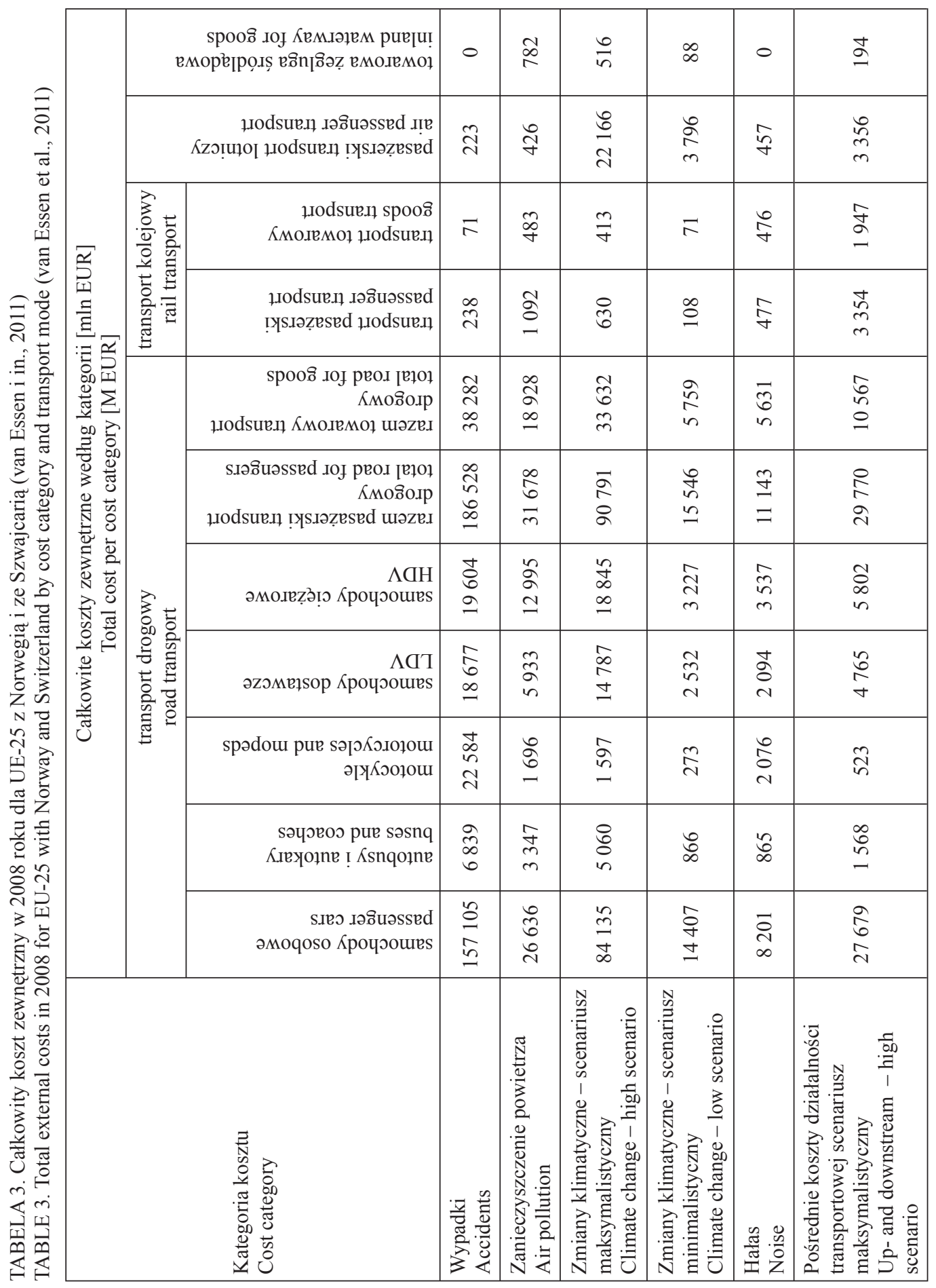




\begin{tabular}{|c|c|c|c|c|c|c|}
\hline$\stackrel{M}{=}$ & छ & 8 & 0 & 0 & $\begin{array}{l}\varrho \\
\beth\end{array}$ & ֶָ \\
\hline 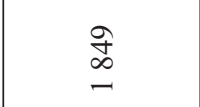 & ঐ̊ & 우 & 0 & 0 & $\begin{array}{l}\hat{\infty} \\
\stackrel{0}{r}\end{array}$ & 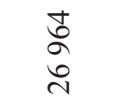 \\
\hline$\stackrel{\infty}{5}$ & $\vec{\sim}$ & - & $\underset{-}{\mathbb{Z}}$ & in & $\begin{array}{l}\stackrel{J}{\Im} \\
\sim\end{array}$ & $\begin{array}{l}0 \\
\text { రె } \\
m\end{array}$ \\
\hline$\widehat{\widehat{\sigma}}$ & $\stackrel{n}{\sim}$ & - & तે & సે & $\hat{\tilde{\sigma}}$ & $\frac{\infty}{\vec{n}}$ \\
\hline $\begin{array}{l}\hat{f} \\
0 \\
0\end{array}$ & $\stackrel{n}{n}$ & $\stackrel{\overrightarrow{0}}{\underline{-}}$ & 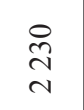 & 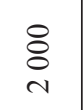 & $\begin{array}{l}n \\
\tilde{n} \\
\vec{\infty}\end{array}$ & $\begin{array}{l}\infty \\
\stackrel{+}{a} \\
\stackrel{\Xi}{=}\end{array}$ \\
\hline $\begin{array}{l}8 \\
\infty \\
=\end{array}$ & $\stackrel{\widetilde{N}}{\stackrel{n}{n}}$ & $\begin{array}{l}\underset{\infty}{\infty} \\
\sim \\
-\end{array}$ & $\begin{array}{l}\hat{0} \\
\stackrel{2}{v}\end{array}$ & $\begin{array}{l}\underset{\sigma}{n} \\
\frac{n}{n}\end{array}$ & $\begin{array}{l}8 \\
\infty \\
i \\
\stackrel{N}{N}\end{array}$ & $\frac{\vec{R}}{\stackrel{0}{0}}$ \\
\hline 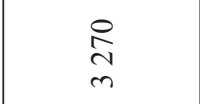 & ָิ & $\tilde{\infty}$ & స్రి & $\ddot{2}$ & 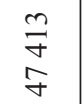 & $\begin{array}{l}\mathbb{d} \\
n \\
n\end{array}$ \\
\hline$\stackrel{ }{\hat{N}}$ & $\underset{\sim}{\mathbb{N}}$ & $\stackrel{\text { ㅇ }}{\circ}$ & $\bar{\delta}$ & $\tilde{o}$ & $\begin{array}{l}\vec{J} \\
\dot{J}\end{array}$ & $\begin{array}{l}+ \\
\infty \\
\infty \\
\infty \\
+\end{array}$ \\
\hline$\stackrel{\sim}{m}$ & $\approx$ & તે & 우 & $\stackrel{\ominus}{=}$ & $\begin{array}{l}\stackrel{n}{N} \\
\text { N }\end{array}$ & $\begin{array}{l}\hat{N} \\
\underset{N}{N}\end{array}$ \\
\hline$\tilde{\infty}$ & 守 & $\stackrel{\sim}{\sim}$ & $\ddot{\infty}$ & $\ddot{\sim}$ & $\begin{array}{l}0 \\
\infty \\
\infty \\
n\end{array}$ & $\begin{array}{l}\hat{n} \\
\infty \\
\infty\end{array}$ \\
\hline $\begin{array}{l}\vec{\sigma} \\
0 \\
0\end{array}$ & $\begin{array}{l}\infty \\
8 \\
m\end{array}$ & 弪 & $\begin{array}{l}\infty \\
\infty \\
\sim\end{array}$ & $\begin{array}{l}\underset{\infty}{\Delta} \\
\nabla\end{array}$ & $\begin{array}{l}\text { N } \\
\text { } \\
\underset{\sim}{n}\end{array}$ & $\begin{array}{l}\stackrel{0}{m} \\
\stackrel{m}{m}\end{array}$ \\
\hline 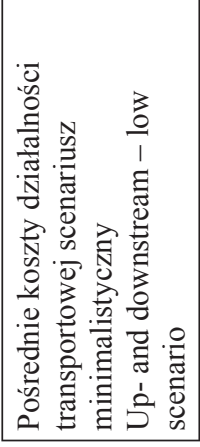 & 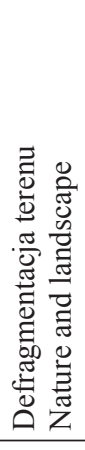 & 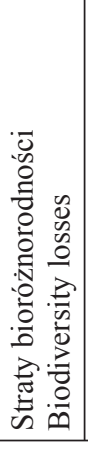 & 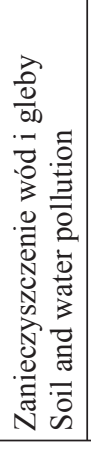 & 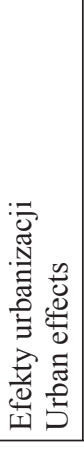 & 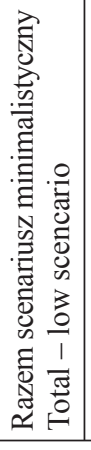 & 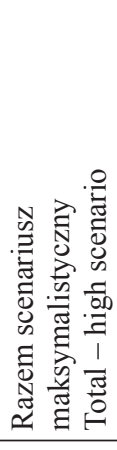 \\
\hline
\end{tabular}


TABELA 4. Koszty zewnętrzne transportu w Polsce w 2014 roku według kategorii kosztów - bez kongestii (badania własne)

TABLE 4. Total external costs in 2014 for Poland by cost category - excluding congestion (own studies)

\begin{tabular}{|c|c|c|c|c|c|}
\hline \multirow[b]{2}{*}{$\begin{array}{l}\text { Kategoria kosztów } \\
\text { Cost component }\end{array}$} & \multicolumn{2}{|c|}{$\begin{array}{l}\text { Transport pasażerski } \\
\text { Passenger transport }\end{array}$} & \multicolumn{2}{|c|}{$\begin{array}{l}\text { Transport ładunków } \\
\text { Goods transport }\end{array}$} & \multirow[b]{2}{*}{$\begin{array}{c}\text { Koszty } \\
\text { transportu } \\
{[\mathrm{mln} \text { EUR] }} \\
\text { Total costs } \\
{[\mathrm{M} \text { EUR] }}\end{array}$} \\
\hline & $\begin{array}{l}\text { udział } \\
\text { w kosztach } \\
\text { share in } \\
\text { costs }[\%]\end{array}$ & $\begin{array}{c}\text { wielkość } \\
\text { kosztów } \\
\text { [mln EUR] } \\
\text { costs } \\
\text { [M EUR] }\end{array}$ & $\begin{array}{l}\text { udział } \\
\text { w kosztach } \\
\text { share in } \\
\text { costs }[\%]\end{array}$ & $\begin{array}{l}\text { wielkość } \\
\text { kosztów } \\
\text { [mln EUR] } \\
\text { costs } \\
\text { [M EUR] }\end{array}$ & \\
\hline $\begin{array}{l}\text { Wypadki } \\
\text { Accidents }\end{array}$ & 47 & 6617,1 & 32 & 2375,3 & 8992,4 \\
\hline $\begin{array}{l}\text { Zanieczyszczenie powietrza } \\
\text { Air pollution }\end{array}$ & 8 & 1186,5 & 17 & 1258,6 & 2445,1 \\
\hline $\begin{array}{l}\text { Zmiany klimatyczne - scenariusz } \\
\text { maksymalistyczny } \\
\text { Climate change - high scenario }\end{array}$ & 29 & 4015,9 & 29 & 2144,9 & 6160,8 \\
\hline $\begin{array}{l}\text { Zmiany klimatyczne scenariusz } \\
\text { minimalistyczny } \\
\text { Climate change - low scenario }\end{array}$ & 5 & 684,5 & 5 & 372,2 & 1056,8 \\
\hline $\begin{array}{l}\text { Hałas } \\
\text { Noise }\end{array}$ & 3 & 433,5 & 5 & 372,2 & 805,8 \\
\hline $\begin{array}{l}\text { Pośrednie koszty działalności } \\
\text { transportowej - scenariusz } \\
\text { maksymalistyczny } \\
\text { Up- and downstream - high } \\
\text { scenario }\end{array}$ & 9 & 1300,6 & 11 & 780,0 & 2080,6 \\
\hline $\begin{array}{l}\text { Pośrednie koszty działalności } \\
\text { transportowej - scenariusz } \\
\text { minimalistyczny } \\
\text { Up- and downstream - low } \\
\text { scenario }\end{array}$ & 5 & 753,0 & 6 & 443,2 & 1196,1 \\
\hline $\begin{array}{l}\text { Defragmentacja terenu } \\
\text { Nature and landscape }\end{array}$ & 1 & 136,9 & 1 & 106,4 & 243,3 \\
\hline $\begin{array}{l}\text { Straty bioróżnorodności } \\
\text { Biodiversity losses }\end{array}$ & 0,3 & 45,6 & 1 & 70,9 & 116,5 \\
\hline $\begin{array}{l}\text { Zanieczyszczenie wód i gleby } \\
\text { Soil and water pollution }\end{array}$ & 1 & 91,3 & 2 & 141,8 & 233,1 \\
\hline $\begin{array}{l}\text { Efekty urbanizacji } \\
\text { Urban effects }\end{array}$ & 1 & 182,5 & 2 & 124,1 & 306,6 \\
\hline $\begin{array}{l}\text { Razem - scenariusz } \\
\text { minimalistyczny } \\
\text { Total - low scencario }\end{array}$ & & 10131,0 & & 5264,7 & 15395,7 \\
\hline $\begin{array}{l}\text { Razem - scenariusz } \\
\text { maksymalistyczny } \\
\text { Total - high scenario }\end{array}$ & & 14010,0 & & 7374,1 & 21384,1 \\
\hline
\end{tabular}


47 i 32\%. Druga kategorią były koszty zmianklimatycznychw scenariuszumaksymalistycznym 29\% w obu rodzajach przewozów. Koszty hałasu miały udział na poziomie 3\% w przewozach osób i 5\% w przewozach ładunków. Udział kosztów defragmentacji terenu, zanieczyszczenia wód i gleby oraz kosztów efektów urbanizacji oszacowano na poziomie $1 \%$, a koszty strat bioróżnorodności na poziomie $0,3 \% \mathrm{w}$ przewozach pasażerskich.

W przewozach towarowych udziały te wyniosły odpowiednio: 1, 2 i $25 \%$, straty bioróżnorodności wyliczono zaś na $1 \%$. Porównując koszty zewnętrzne przewozów osób i ładunków, znaczna część tych kosztów, bo aż $66 \%$, dotyczyła transportu pasażerskiego, zwłaszcza motoryzacji indywidualnej. Na transport towarowy przypadło 34\% kosztów. Największy udział w kosztach zewnętrznych miały podróże samochodami prywatnymi i wyniosły 11,5 mld EUR, co stanowiło 54\% kosztów zewnętrznych transportu w 2014 roku.

\section{Wnioski}

Osiagnnięcie zrównoważonego rozwoju transportu jawi się jako główny priorytet polityki transportowej we współczesnym świecie. O ile jednak jeszcze kilkanaście lat temu wskazywano przede wszystkim na uwarunkowania i bariery wprowadzania w życie działań wpływających na redukcję kosztów zewnętrznych, o tyle obecnie już precyzyjnie można określić, które $\mathrm{z}$ najbardziej efektywnych instrumentów cenowych przynieść mogą najbardziej oczekiwane rezultaty. Unia Europejska po ponad 25 latach realizowania polityki transportowej zmierzającej w kierunku zrównoważonego rozwoju transportu doprowadziła do opracowania konkretnych założeń metodologicznych w zakresie szacunku kosztów zewnętrznych transportu. To pewien etap wspólnych działań i sukces decydentów, trudno bowiem wyobrazić sobie kolejne etapy internalizacji kosztów zewnętrznych czy reformy opłat transportowych bez jasnego podejścia do problemu kalkulacji kosztów.

Konstruowanie i wdrażanie odpowiednich instrumentów polityki transportowej wymaga dostępu do niezbędnych informacji umożliwiających określenie poprawnych w danych realiach celów, wskazania na konkretne zadania do realizacji czy wreszcie dobrania odpowiednich instrumentów. W polityce transportowej nie do przecenienia jest diagnoza poziomu kosztów i przychodów w transporcie, w ujęciu krajowym, z wyszczególnieniem poszczególnych gałęzi transportu. W Polsce brak jest pełnego szacunku kosztów zewnętrznych transportu. Jedynie koszty wypadków drogowych zostały wyliczone według rekomendowanych przez Komisję Europejską metod. Stąd bardzo ważne jest podjęcie w najbliższym czasie prac nad wykonaniem takich szacunków. Sama Komisja Europejska w 2017 roku podjęła działania w kierunku uaktualnienia podręcznika w zakresie metod szacunku kosztów zewnętrznych transportu.

W Polsce, jak dotad nie przeprowadzono badań szacujących wielkość kosztów zewnętrznych transportu. Można znaleźć jedynie fragmentaryczne kalkulacje. Z przeprowadzonych przez autorkę estymacji kosztów zewnętrznych transportu w Polsce wynika, że są one znacznym obciążeniem dla polskiego 
społeczeństwa i gospodarki narodowej. Stanowia one bowiem około 5\% PKB W wariancie maksymalnym i 3\% w wariancie minimalnym. Największy udział w tych kosztach zajmują koszty wypadków drogowych, które wynoszą 42\% $\mathrm{w}$ wariancie maksymalnym i 58\% w wariancie minimalnym. Wielkości te pokazują obszary, w których konieczne jest podjęcie dodatkowych działań w zakresie bieżącej polityki transportowej. Zagadnienia bezpieczeństwa $\mathrm{w}$ transporcie, w tym szczególnie w transporcie drogowym, sa od co najmniej 20 lat priorytetowe. Wielkość kosztów zewnętrznych wypadków transportowych pokazuje jednak, że działania i środki, podejmowane w celu poprawy sytuacji w tym zakresie są niewystarczające i wymagają przeformatowania.

Największy udział w strukturze kosztów zewnętrznych mają podróże samochodami prywatnymi i stanowią aż $54 \%$ całkowitych kosztów zewnętrznych transportu. To pokazuje, do kogo powinny być adresowane instrumenty polityki transportowej, które mają na celu działania na rzecz kształtowania proekologicznej struktury gałęziowej przewozów.

Innym wnioskiem płynącym z przeprowadzonych badań jest konieczność poprawy dostępności do danych, które można byłoby wykorzystać do przeprowadzenia szacunków. Obecnie podejmowane są prace nad poprawą dostępności danych i odpowiednią ich dezagregacją. Główny Urząd Statystyczny jesienią 2017 roku rozpoczął projekt badawczy w tym zakresie.

\section{Literatura}

Baumol, W.J. i Oates, W.E. (1988). The theory of environmental policy. Cambridge: Cambridge University Press.

Bąk, M. i Pawłowska, B. (2008). Koszty zewnętrzne transportu w Unii Europejskiej - od wizji politycznej do jednolitych metod kalkulacji. Przeglad Komunikacyjny, 7-8, 22-41.

European Commission, EC (1995). Green Paper: Towards fair and efficient pricing in transport. Policy options for internalising the external costs of transport in the European Union. COM (95)691 final. Brussels 20.12.1995.

European Commission, EC (2014). Update of the Handbook on External Costs of Transport. Final Report. Ricardo-AEA/R/ ED57769. London: Ricardo-AEA.

van Essen, H., Schroten, A., Otten, M., Sutter, D., Schreyer, Ch., Zandonella, R. i Doll, C. (2011). External Costs of Transport in Europe. Update study for 2008. Delft: CE Delft.

Koźlak, A. (2012). Nowoczesny system transportowy jako czynnik rozwoju regionów $w$ Polsce. Gdańsk: Wydawnictwo Uniwersytetu Gdańskiego.

Link, H., Becker, A., Matthews, B., Wheat, P., Enei, R., Sessa, C. i Lindberg, G. (2007). Monitoring Pricing Policy Using Transport Accounts. Deliverable D5. GRACE project. Leeds: ITS.

Maibach, M.C. Schreyer, D., Sutter, H.P., van Essen, B.H., Boon, R., Smokers, A. i Bąk, M. (2008). Handbook on estimation of external costs in the transport sector. Delft: Internalisation Measures and Policies for All External Cost of Transport (IMPACT), CE Delft.

Parlament Europejski (2009). Obliczanie kosztów zewnętrznych $w$ sektorze transportu. IP/B/TRAN/FWC/2006 156/Lot7-C1-SC4. Bruksela: Dyrekcja Generalna ds. Polityki Wewnętrznej, Parlament Europejski.

Pawłowska, B. (2000). Zewnętrzne koszty transportu. Problem ekonomicznej wyceny. Gdańsk: Wydawnictwo Uniwersytetu Gdańskiego. 
Pawłowska, B. (2013). Zrównoważony rozwój transportu na tle wspótczesnych problemów połeczno-gospodarczych. Gdańsk: Wydawnictwo Uniwersytetu Gdańskiego.

Pawłowska, B. (2017). An overview of the progress towards sustainable transport development by using TERM indicators. W: M. Suchanek (red.), Sustainable transport development innovation and technology. Proceedings of the 2016 TranSopot Conference (pp. 27-46). Springer.

Rothengater W., (2000). External Effects of Transport. W: J.B. Polak i A. Heertje (red.), Analytical transport economics. An International Perspective (pp. 79-116). Cheltenham: Edward Elgar Publishing.

\section{Streszczenie}

Koszty zewnętrzne transportu w Polsce. Rozwój sektora transportowego jest bardzo ściśle powiązany $\mathrm{z}$ procesem rozwoju społeczno-gospodarczego na zasadzie sprzężeń zwrotnych. Transport zbliża do siebie rynki, umożliwia zwiększenie produkcji, aktywizuje regiony wokół infrastruktury, czyli umożliwia pozostałym działom sprawne funkcjonowanie. Transport jest też źródłem wielu znaczących, negatywnych dla społeczeństwa i gospodarki efektów zewnętrznych. Okazuje się również, że pomimo wieloletnich doświadczeń $\mathrm{w}$ badaniach skutków i kosztów zewnętrznych transportu nadal istnieją duże rozbieżności w ujęciach i metodach badawczych, a także w terminologii oraz zasadach definiowania pojęć. Celem artykułu jest przegląd dostępnych badań nad szacunkami kosztów zewnętrznych i estymacja tych kosztów dla transportu w Polsce z wykorzystaniem metod zalecanych przez Komisję Europejską. Wiedza na temat wielkości kosztów zewnętrznych transportu jest podstawą działań w zakresie internalizacji tych kosztów i doboru właściwych instrumentów polityki transportowej.

\section{Summary}

External costs of transport in Poland. The development of transport sector is very closely linked to the process of socio-economic development. The interrelations between transport and economic growth are complex and there are many feedbacks. Transport has a vital role - it brings the markets closer together, increases production, activates regions around the infrastructure, enabling other sectors to function smoothly. Transport is also the source of many significant negative externalities for the environment, society and economy. It also turns out that, despite many years of experience in the study of the external effects and costs of transport, there are still large discrepancies in approaches and research methods, as well as terminology and rules for defining the concepts. The aim of this article is to review available studies on the estimation of external costs and to estimate these costs for transport in Poland using methods recommended by the European Commission. Knowledge of the cost external of transport is the basis for the internalisation of these costs and it allow to choose the most effective transport policy instruments.

\section{Author's address:}

Barbara Pawłowska

Uniwersytet Gdański

Wydział Ekonomiczny

Katedra Ekonomiki Transportu

81-824 Sopot, ul. Armii Krajowej 119/121

Poland

e-mail: bpawlowska@ug.edu.pl 